\title{
An Economic Evaluation of Kisan Credit Card in Bhabua District of Bihar, India
}

\author{
Vijay Bahadur Gupta ${ }^{1 *}$, Babu Singh ${ }^{1}$ and R. Ranjan ${ }^{2}$ \\ ${ }^{1}$ Department of Agricultural Economics, College of Agriculture, C.S.A. University of \\ Agriculture \& Technology, Kanpur, 208002, India \\ ${ }^{2}$ Krishi Vigyan Kendra (ICAR-NRRI-CRURRS) Koderma, Jharkhand 825324, India \\ *Corresponding author
}

\section{Keywords \\ Kisan credit card, \\ Economic evaluation, \\ Cobb Douglas production \\ function, Agriculture \\ growth, Cropping Pattern, \\ Punjab national Bank \\ Article Info \\ Accepted: \\ 17 January 2018 \\ Available Online: \\ 10 February 2018}

\section{A B S T R A C T}

Kisan Credit Card (KCC) scheme was started by Government of India in year 1998-99 to provide adequate and timely support from the banking system to the farmers in a flexible and cost effective manner. The study has been undertaken to evaluate Kisan credit Card scheme in Bhabua district of Bihar. The study used both primary and secondary data on KCC issued and amount sanctioned collected from District Lead Banks and primary data relating to production, income, borrowing, repayments, interest and cost of borrowing, opinion of borrower etc. collected from $60 \mathrm{KCC}$ and 60 non-KCC sample borrowers. The results revealed that though the Kisan Credit Card scheme was initially restricted to the farmers who had good track record of repayment, later it was extended to those who have production credit need of Rs.5000 and above. In the Bhabua district there was high positive growth in both the number of KCC issued (393.38\%) and amount sanctioned $(230.52 \%)$. The total credit cost as percentage of amount borrowed was higher in the non KCC category as compare to that in the KCC. In all the major crops the credit provided under both KCC and non-KCC categories was found adequate but the credit gap was less in KCC as compare to that in non-KCC category. The scheme of Kisan Credit Card should be extended to cover all the farmers which will help not only in reducing cost of credit but also to get adequate amount of credit.

\section{Introduction}

India lives in villages. The majority of our country's population depends upon agriculture. Agriculture has got an important role in Indian Economy. The growth of Indian economy depends upon the growth and performance of agricultural and allied sector. Agriculture also plays a crucial role in industrial development of our nation as it is the source of raw materials for many industries. Agriculture contributes a large share in the country's gross domestic product. Its share in total GDP in 1950-51 was around $55 \%$. It has come down to $17 \%$ in 2013-14 (Economy of Indian- Wikipedia). However, the importance of this sector cannot be under estimated for growths of Indian economy. To maintain the growth and performance of Indian economy, thus, there is need to sustain the growth of agriculture sector. In this respect sustained growth of agricultural sector, credit 
plays a crucial role. Considering the problems being faced by the farmers in having access to credit, Shri Yashwant Sinha, the then Union Minister of Finance, in his 1998-99 Budget Speech on 01 June 1998 introduced the 'Kisan Credit Card' (KCC) Scheme as "NABARD is being asked to formulate a model scheme for issue of Kisan Credit Cards to farmers on the basis of their holdings for uniform adoption by the banks so that the farmers may use them to readily purchase agricultural inputs such as seeds, fertilizers, pesticides etc. and draw cash for their production needs." The model scheme was circulated to Commercial Banks, Co-operative Banks and Regional Rural Banks in August 1998.

This scheme has facilitated the availability of credit in time and has simplified the procedure for availing loan from banks to a large extent (Nahatkar et al., 2002). The timely availability of crop loan has helped the farmers realize higher returns from farming (Singh and Sekhon, 2005). Most of the farmers are aware about the benefits of the KCC scheme irrespective of their literacy level (Vedini and Durga, 2007). The cumulative number of KCC cards issued since inception (1988-89) till March 2015 had reached to 14.64 crore. The number of operative/ live $\mathrm{KCC}$ as on 31 March 2015 stood at 7.41 crore. This achievement is against the total operational land holdings estimated at 13.83 crore by Agricultural Census (2010-11) or number of agricultural households estimated at 9.02 by National Sample Survey Organization (Department of Economic Analysis and Research (DEAR), NABARD, 2016). Also, there is a gap between the amount required and sanctioned for crop production and other activities. A number of farmers have diverted loan amount towards purposes other than for which it was taken (Rao and Sahu, 2005). In spite of various measures to rejuvenate farm credit, the flow of credit to agriculture sector remained quantitatively and qualitatively poor.
One of the main reasons for this is the complex procedures followed by the institutional agencies and also the inadequacy and untimely supply of credit. It is appropriate to study the economic evaluation of this scheme since it has completed more than one decade. Hence, the present study was formulated in Bhabua district of Bihar with the specific objectives to analyze the growth in the number of Kisan Credit Card users, to analyze cost of credit and the adequacy of credit provided under $\mathrm{KCC}$ in comparison with credit without $\mathrm{KCC}$.

\section{Materials and Methods}

The purposive sampling method was followed to select the Bhabua districts of Bihar. One branch in bhabua district which has made a good progress in implementing Kisan Credit Card scheme was selected. In branch, 20 small farmers (less than $2 \mathrm{ha}$ ), 20 medium farmers (2.01 ha to 4 ha) and 20 large farmers (above 4 ha) were randomly selected. To make a comparison, data were also collected from 60 non-beneficiary farmers of the district. Thus, study was based on the information obtained from $60 \mathrm{KCC}$ and 60 non-KCC borrowers spread across bhabua district of Bihar. Both secondary and primary data on KCC were used in the study.

The secondary data on the number of KCC issued, amount of loan sanctioned by institutions and by regions were collected from various publications of NABARD, RBI and GoI (2011-12). The primary data were collected using pre-structured schedule on such aspects as farm production, perception of farmers about the KCC scheme, income, borrowing, repayments, interest, cost of borrowing, assets position, opinion of borrower etc. The Cobb Douglas production function was fitted to assess the resource-use efficiency among the KCC beneficiary as well as non-beneficiary farmers. 


\section{Results and Discussion}

\section{Growth in the number of Kisan Credit Card users}

In order to study agency-wise status of KCC issued in India, the secondary data was collected, analyzed and presented in Table 1. Up to the end of February 2012, total KCC issued in India were 808 lakh, which were 7.84 lakh in the year 2001-02. Out of the total KCC issued, the Co-operative banks were issued 358.63 lakh (44.38 \%) whereas the Commercial banks and Regional Rural Banks were issued 336.74 lakh and 112.63 lakh (41.67\% and $13.93 \%)$ respectively. For the Co-operative banks and Commercial banks lot of variations has been seen in issuing $\mathrm{KCC}$ on the other hand the Regional Rural Banks have shown a steady growth in issuing KCC. The compound growth rate for total $\mathrm{KCC}$ issued in India was 10.30 per cent per annum. The Cooperative banks showed 2.78 per cent annual compound growth rate whereas the Regional Rural Banks and Commercial banks registered 43.25 per cent and 14.67 per cent (both significant at 1 per cent) annual compound growth rate.

From Table 2 indicated that status of $\mathrm{KCC}$ in Bihar states. In the first year (2002-03) of implementation of $\mathrm{KCC}$ scheme, the Bihar state had issued 4.09 lakh. As the central government has made KCC compulsory for any type of crop loan there was high growth in issuing of $\mathrm{KCC}$ in recent years. The annual compound growth rate of $\mathrm{KCC}$ is issued in state $(24.96 \%)$.

From the above table 3 reveal that growth in the issue of KCC in the study area, the secondary data was collected from the respective district lead banks (panjab national bank). The year wise data on number of KCC issued and amount sanctioned was not available with the District Lead Bank (DLB).
However, the data was available for recent years. This led to analyze only recent few years (only 2010 and 2011) data. Table 3, represented that in the year 2010-11 the KCC issued in the Bhabua district were 11299 and the amount sanctioned through KCC was 9306 lakh. In the year 2011-12 both the KCC issued and amount sanctioned through $\mathrm{KCC}$ in the Bhabua district increased to the 9306 and 6524 lakh Rs. (32.82\% and 12.17\%) respectively.

\section{Cropping pattern of sample farmers}

In kharif season, the major crops grown by the sample farmers (Table 4) were Paddy and potato In rabi season, the major crops grown were Wheat and Gram. In summer season, the crops grown were Ground nut and Maize, besides this some farmers had planted Banana. The average area under paddy crop in the kharif season was 0.77 ha in $\mathrm{KCC}$ category where as in non KCC category it was 0.86 ha. The area under wheat was 0.76 ha and 0.84 ha respectively for $\mathrm{KCC}$ and non $\mathrm{KCC}$ farmers. The average area under different crops has been presented in table 4. The gross cropped area under KCC category was 3.97 ha while in the case of non KCC it was 4.31 ha. The cropping intensity was 145 per cent for KCC farmers where as it was 162 per cent for non $\mathrm{KCC}$ farmers.

\section{Resource use efficiency}

The Cobb-Douglas production function was estimated to analyse relationship between resource and productivity of major crops using survey data from sample farmers.

The gross income in rupees realized from the crop output was taken as dependent variable while expenditure made on seed (Rs), fertilizers and manures (Rs), labours (Rs) and irrigation (Rs) were taken as independent variables. 
Table.1 Agency-wise status of KCC issued in India (in lakh numbers)

\begin{tabular}{|c|c|c|c|c|}
\hline Year & $\begin{array}{l}\text { Cooperative } \\
\text { banks }\end{array}$ & RRBs & $\begin{array}{l}\text { Commercial } \\
\text { banks }\end{array}$ & Total \\
\hline 2001-02 & $1.56(19.90)$ & $\begin{array}{l}0.06 \\
(0.77)\end{array}$ & $6.22(79.34)$ & $\begin{array}{l}7.84 \\
(100.00)\end{array}$ \\
\hline $2002-03$ & $35.95(70.02)$ & $\begin{array}{l}1.73 \\
(3.37)\end{array}$ & $13.66(26.61)$ & $\begin{array}{l}51.34 \\
(100.00)\end{array}$ \\
\hline 2003-04 & $56.14(64.89)$ & $\begin{array}{l}6.48 \\
(7.49)\end{array}$ & $23.90(27.62)$ & $\begin{array}{l}86.52 \\
(100.00)\end{array}$ \\
\hline 2004-05 & $54.36(58.19)$ & $\begin{array}{l}8.34 \\
(8.93)\end{array}$ & $30.71(32.30)$ & $\begin{array}{l}93.41 \\
(100.00)\end{array}$ \\
\hline $2005-06$ & $45.79(55.50)$ & $\begin{array}{l}9.64 \\
(11.70)\end{array}$ & $27.00(32.75)$ & $\begin{array}{l}82.43 \\
(100.00)\end{array}$ \\
\hline 2006-07 & $48.78(57.75)$ & $\begin{array}{l}12.74 \\
(13.80)\end{array}$ & $30.94(33.46)$ & $\begin{array}{l}92.46 \\
(100.00)\end{array}$ \\
\hline $2007-08$ & $35.56(36.73)$ & $\begin{array}{l}17.29 \\
(17.86)\end{array}$ & $43.95(45.40)$ & $96.80(100.00)$ \\
\hline 2008-09 & $25.98(32.42)$ & $\begin{array}{l}12.49 \\
(15.60)\end{array}$ & $41.65(51.98)$ & $80.12(100.00)$ \\
\hline 2009-10 & $22.97(30.74)$ & $\begin{array}{l}14.06 \\
(18.80)\end{array}$ & $48.08(49.08)$ & $85.11(100.00)$ \\
\hline 2010-11 & $20.91(24.69)$ & $\begin{array}{l}17.73 \\
(20.93)\end{array}$ & $46.06(54.38)$ & $\begin{array}{l}84.70 \\
(100.00)\end{array}$ \\
\hline 2011-12\# & $10.63(22.49)$ & $\begin{array}{l}12.06 \\
(25.51)\end{array}$ & $24.57(51.98)$ & $47.26(100.00)$ \\
\hline Total & $358.63(44.38)$ & $\begin{array}{l}112.63 \\
(13.93)\end{array}$ & $336.74(41.67)$ & $808.00(100.00)$ \\
\hline CGR (\%) pa & 2.78 & $43.25 * *$ & $14.53 * *$ & 10.30 \\
\hline
\end{tabular}

\#Up to Feb. 2012

**significant at 1 per cent

Note: Figures in parentheses are percentages to annual row total.

Source: Government of India, Economic Survey, 2011-12.

Table.2 Status of KCC in Bihar State (in lakh numbers)

\begin{tabular}{|c|c|}
\hline Year & Bihar \\
\hline $2002-03$ & 4.09 \\
$2003-04$ & 10.87 \\
$2004-05$ & 9.15 \\
$2005-06$ & 8.43 \\
$2006-07$ & 3.00 \\
$2007-08$ & 5.90 \\
$2008-09$ & 7.78 \\
$2009-10$ & 11.31 \\
$2010-11$ & 9.24 \\
$2011-12$ & 8.87 \\
\hline Total & $\mathbf{7 8 . 6 4}$ \\
\hline
\end{tabular}


Table.3 Growth in Kisan Credit Cards issued in the study area

\begin{tabular}{|c|c|c|c|c|c|c|c|}
\hline \multirow[b]{2}{*}{$\begin{array}{l}\text { SI. } \\
\text { No. }\end{array}$} & \multirow[b]{2}{*}{ Districts } & \multicolumn{2}{|c|}{ 2010-11 } & \multicolumn{2}{|c|}{ 2011-12 } & \multicolumn{2}{|c|}{ Per cent change } \\
\hline & & $\begin{array}{l}\text { KCC } \\
\text { issued }\end{array}$ & $\begin{array}{c}\text { Amount } \\
\text { sanctioned } \\
\text { (in lakhs } \\
\text { Rs.) }\end{array}$ & $\begin{array}{l}\text { KCC } \\
\text { issued }\end{array}$ & $\begin{array}{c}\text { Amount } \\
\text { sanctioned } \\
\text { (in lakhs } \\
\text { Rs.) }\end{array}$ & $\begin{array}{l}\text { KCC } \\
\text { issued }\end{array}$ & $\begin{array}{l}\text { Amount } \\
\text { sanctioned } \\
\text { (in lakhs } \\
\text { Rs.) }\end{array}$ \\
\hline 1. & Bhabua & 11299 & 9306 & 15448 & 6524 & 32.82 & 12.17 \\
\hline
\end{tabular}

Table.4 Cropping pattern and major crops grown by the respondents during the year 2011-12

\begin{tabular}{|l|l|l|l|l|l|}
\hline \multirow{2}{*}{$\begin{array}{c}\text { Cropl } \\
\text { Season }\end{array}$} & $\begin{array}{l}\text { Small } \\
(\mathbf{n = 3 0})\end{array}$ & $\begin{array}{l}\text { Medium } \\
(\mathbf{n = 2 0})\end{array}$ & $\begin{array}{l}\text { Small } \\
(\mathbf{n = 3 0})\end{array}$ & $\begin{array}{l}\text { Nedium } \\
(\mathbf{n = 2 0})\end{array}$ & $\begin{array}{c}\text { All } \\
(\mathbf{n = 1 0 0})\end{array}$ \\
\hline Kharif & $\begin{array}{l}\text { Area } \\
\text { (ha) }\end{array}$ & Area (ha) & $\begin{array}{l}\text { Area } \\
\text { (ha) }\end{array}$ & $\begin{array}{l}\text { Area } \\
\text { (ha) }\end{array}$ & $\begin{array}{l}\text { Area } \\
\text { (ha) }\end{array}$ \\
\hline $\begin{array}{l}\text { Paddy } \\
\text { Potato }\end{array}$ & 0.20 & 1.56 & 0.22 & 1.84 & 0.86 \\
\hline Rabi & 0.12 & 1.32 & 0.02 & 1.20 & 0.15 \\
\hline $\begin{array}{l}\text { Wheat } \\
\text { Gram }\end{array}$ & & & & & \\
\hline & 0.22 & 1.04 & 0.00 & 1.02 & 0.24 \\
\hline
\end{tabular}

Table.5 Cost and Returns from the major crops

\begin{tabular}{|c|c|c|c|c|c|c|}
\hline \multirow[t]{2}{*}{ Cost } & \multicolumn{3}{|c|}{$\mathrm{KCC}$} & \multicolumn{3}{|c|}{ NonKCC } \\
\hline & wheat & Paddy & Potato & wheat & Paddy & Potato \\
\hline TVC (Rs.) & $\begin{array}{c}10458.22 \\
(52.71)\end{array}$ & $\begin{array}{c}18086.03 \\
(62.94)\end{array}$ & $\begin{array}{c}37680.33 \\
(66.95)\end{array}$ & $\begin{array}{c}19208.34 \\
(68.22)\end{array}$ & $\begin{array}{c}16826.74 \\
(61.47)\end{array}$ & $\begin{array}{c}34268.33 \\
(60.58)\end{array}$ \\
\hline TFC (Rs.) & $\begin{array}{c}9335.92 \\
(56.04)\end{array}$ & $\begin{array}{c}10648.47 \\
(37.47)\end{array}$ & $\begin{array}{c}19322.00 \\
(33.05)\end{array}$ & $\begin{array}{c}9647.17 \\
(31.77)\end{array}$ & $\begin{array}{c}15544.72 \\
(38.52)\end{array}$ & $\begin{array}{c}22280.29 \\
(39.74)\end{array}$ \\
\hline TC (Rs.) & $\begin{array}{c}19794.14 \\
(100.00)\end{array}$ & $\begin{array}{c}28734.50 \\
(100.00)\end{array}$ & $\begin{array}{c}56627.47 \\
(100.00)\end{array}$ & $\begin{array}{c}28855.51 \\
(100.00)\end{array}$ & $\begin{array}{c}27372.16 \\
(100.00)\end{array}$ & $\begin{array}{c}56548.52 \\
(100.00)\end{array}$ \\
\hline $\begin{array}{c}\text { Yield }(q) \\
\left(t^{*}\right)\end{array}$ & 32.62 & 38.82 & 67.99 & 31.64 & 37.38 & 66.86 \\
\hline $\begin{array}{c}\text { Gross } \\
\text { return } \\
\text { (Rs.) }\end{array}$ & 31320.62 & 42716.41 & 84842.78 & 33100.66 & 41118.00 & 83427.95 \\
\hline $\begin{array}{l}\text { Net return } \\
\text { (Rs.) }\end{array}$ & 11526.48 & 13981.66 & 28215.75 & 4245.15 & 13745.84 & 26879.43 \\
\hline
\end{tabular}




\section{Resource use efficiency in paddy}

From table 5, the estimated parameters of seed, fertilizers and manures and irrigation were negative for all farmers in KCC category indicated that for every one per cent increase in the expenditure on seed, fertilizers and manures and irrigation would result in decreased gross return by 0.05 per cent, 0.09 per cent and 0.01 per cent respectively. The coefficient of labour was positive and significant at one per cent for all farmers in KCC indicated that one per cent increase in labours would result in increasing gross income by 0.91 per cent. In the case of all farmers under non KCC category, the estimated parameters of fertilizers and manures, irrigation (significant at one percent) and labours were positive. This indicated that for every one per cent increase in the use of these resources would result in increased gross return by 0.10 per cent, 0.04 per cent and 1.14 per cent respectively. The coefficients of seed was negative for all farmers in non $\mathrm{KCC}$ indicating that one per cent increased use would result in decreasing gross income by 0.41 per cent.

\section{Resource use efficiency in potato}

From table 5, the estimated parameters of seeds, irrigation and labours were positive for all farmers in KCC category indicating that for every one per cent increase of these inputs would result in increased gross return by 0.33 per cent, 0.30 per cent and 0.003 per cent respectively. The coefficient of fertilizers and manure was negative for all categories of farmers in KCC indicating that one per cent increase in it would result in decreasing gross income by 0.12 per cent. In non KCC category, the estimated parameters of seed, fertilizers and manures and labours were positive indicating that for every one per cent increase in the use of these inputs would result in increased the gross return by 0.54 per cent, 0.02 per cent and 0.44 per cent respectively. The coefficient of irrigation was negative for all farmers in non KCC indicating small negative impact on the gross return. The number of observations for small farmers was not sufficient to run the regression.

\section{Identification of the constraints}

With regard to adequacy of credit, large number of farmers under KCC opined that the credit was adequate $(55 \%)$ but under non KCC they opined that it was inadequate $(61.67 \%)$. About the timeliness 81.67 per cent farmers under KCC felt that the credit provided was timely as against this 86.67 per cent of the farmers under non KCC opined that credit provided was untimely. The large number of the farmers in both the categories opined that the rate of interest was high (61.67\% in KCC and $93.33 \%$ in non KCC). As regards the repayment terms was concerned, majority of the farmers in both the categories felt that it was easy $(98.33 \%$ and $51.67 \%$ ). Majority of the farmers expressed easy accessibility of the bank credit and it was within their reach. According to opinion of bank managers in Bhabua district the number of KCC issued was satisfactory (90 \%). Nearly all the bank Managers in the study area agreed that the procedure followed for issuing the Kisan Credit Card was simple and favorable to the farmers. As far as recovery percentage of loan under KCC was concerned, nearly all bank managers in the study area felt that it was good and satisfactory.

The negative growth in number of Kisan Credit Cards issued and amount sanctioned in last few years indicated the lack of interest either on the part of farmers or on the part of bankers. Hence, more efforts should be made by the banks to reach maximum farmers. The farmers need to be educated and encouraged 
about this innovative credit scheme. Though the RBI and NABARD have circulated to banks to consider the ancillary activities related to crop production while fixing credit limit under KCC, the banks in the study area have not followed. Hence, banks are suggested to consider the ancillary activities while fixing credit limit. This ensures bridging the credit gap. The interest paid per every hundred rupee borrowed was much less for Kisan Credit Card borrowers than that for other borrowers. The non-interest cost component of borrowing can be substantially reduced through the KCC scheme since there is no need to resubmit the loan documents for each borrowing as in the case of non $\mathrm{KCC}$ scheme. The loan documents once produced will be valid for three years. Hence, the scheme of Kisan Credit Card should be extended to cover all the farmers which will help in reducing interest cost of credit.

The resource use efficiency analysis clearly indicated that the seeds, fertilizers and irrigation are not used properly as guided by the economic principles. The farmers need to be educated and advised about the proper use of seed, fertilizers and irrigation. It has been noticed that the illiterate farmers have been excluded from the KCC scheme, the banks should include such farmers in order to extend the coverage of the scheme. The credit under KCC was restricted to crop loan only. It needs to be expanded to cover medium term loans if not long term loans

\section{References}

Gyanendra Mani. (2016) Study on Implementation of Kisan Credit Card Scheme. Published by National Bank for Agriculture and Rural Development, Department of Economic Analysis and Research, 4th Floor, 'C' Wing, Plot No. C-24, G-Block, PB No. 8121, BandraKurla Complex, Bandra (East), Mumbai - 400051

https://en.wikipedia.org/wiki/Economy_of_In dia

Nahatkar, S.B., Mishra, P.K., Raghuwanshi, N.K. and Beohar, B.B. (2002). An evaluation of Kisan Credit Card scheme: A case study of Patan tehsil of Jabalpur district of Madhya Pradesh, Indian Journal of Agricultural Economics, 57(3):578.

Rao, K.R.P. and Sahu, S. (2005) Study of the Kisan Credit Card Scheme and its Initiatives of Orissa State Cooperative Bank, College of Agricultural Banking, Reserve Bank of India, Pune.

Singh, H. and Sekhon, M.K. (2005) Cash in benefits of the Kisan Credit Card Scheme: Onus is upon the farmer, Indian Journal of Agricultural Economics, 60(3):319- 334.

Vedini, K.H. and Durga, P.K. (2007) Evaluation of Kisan Credit Card Scheme in the state of Andhra Pradesh, Indian Journal of Agricultural Economics, 61(1): 365.

\section{How to cite this article:}

Vijay Bahadur Gupta, Babu Singh and Ranjan, R. 2018. An Economic Evaluation of Kisan Credit Card in Bhabua District of Bihar, India. Int.J.Curr.Microbiol.App.Sci. 7(02): 1862-1868. doi: https://doi.org/10.20546/ijcmas.2018.702.224 